\author{
G.T. Urazbayeva ${ }^{1}$, A.A. Kabdiyeva ${ }^{1, *}$ \\ ${ }^{1}$ L.N. Gumilyov Eurasian National University, Nur-Sultan, Kazakhstan \\ (E-mail:akmaralkabdi@gmail.com)
}

\title{
Formation of communicative competence in a professionally-oriented foreign language course in higher education: issues and recommendations
}

\begin{abstract}
The aim of a professionally-oriented English language course is to develop students' communicative competence, English language linguistic competence, in particular, that supports students' professional expertise. In this paper, the main issues of the formation of communicative competence in a professionally - oriented English language course at the university level are discussed. The data is drawn from the survey conducted among undergraduate and postgraduate students in Nur-Sultan, Kazakhstan ( $N=48$, mean age 26.5) who have taken the course. The survey results revealed that although students hold a positive attitude towards the course, they did not show some sufficient improvement of linguistic skills after the course completion, and more than $33 \%$ of respondents rarely or almost never used the acquired English language skills for their further professional development. In this paper, I argue that to reach the intended learning objectives of the course, there is a need for university teachers to create a more «authentic» environment in order to involve students in creative and engaging classroom activities.
\end{abstract}

Keywords: professionally-oriented English, communicative competence, linguistic competence, ESP, EVP, undergraduate students, postgraduate students, language skills.

\section{Introduction}

The main objective of the professionally-oriented English language course at the university level is to develop the communicative competence of students. Upon the course completion, according to Gondová, D., Sipošová, M (2010), students should demonstrate sufficient language proficiency in English language, ability to express their intentions in English language clearly, produce coherent written texts, and apply both verbal and non-verbal communication strategies [1; c. 35]. In Hymes (1972) communicative competence is defined as «knowing what to say to whom in what circumstances and how to say it» [2]. In this regard, Canale \& Swain (1980) distinguish four components of communicative competence, such as linguistic, sociolinguistic, discourse, strategic [3]. If linguistic competence means the knowledge of the language, sociolinguistic competence suggests the knowledge of language use (e.g. certain register, politeness, etc. in a particular situation). When it comes to discourse competence, the ability of a learner to combine language structures into different types of texts is considered. Strategic competence, in turn, means the knowledge of strategies applied in verbal and non-verbal communication.

In the European context, drawing on the Basturkmen's (2012) classification of English for specific purposes [4], English for vocational purposes can be attributed to English for General Vocational Purposes or English for Specific Vocational Purposes. In Widodo (2016), English for Vocational Purposes is defined as an English language programme for both the secondary education and tertiary education levels, to equip students with English language linguistic competence that supports students' vocational expertise [5]. In other words, students from both secondary education (e.g., technical schools) and higher education (e.g., colleges and polytechnics), from different majors (e.g. accounting, hotel hospitality, computer engineering, or tourism management, etc.) are placed into English language courses that cater students' needs to build vocational knowledge and skills in English language. In designing such a programme, English language is integrated into vocational content (with selected English language materials based on vocational tasks, topic, vocabulary, etc.). Widodo (2016) notes that the role of English as a medium of vocational communication to explain the vocational content, develop disciplinary language, vocational knowledge and skills and communicate vocational expertise [5].

Likewise, professionally-oriented English language course in the context of the Kazakhstani education system, pursues the similar objectives as English for Vocational Purposes. Curricula of the professionally-

\footnotetext{
*Corresponding author's e-mail: akmaralkabdi@gmail.com
} 
oriented English language course are skills-based with the objectives to equip students with listening, writing, reading and speaking skills to apply in their future professional carrier (when students go out to work).

In fact, there is a number of legislative documents in the Kazakhstani education system that promote professional education in English language. For example, in the State Program for Development of technical and vocational education in the Republic of Kazakhstan for 2005-2010 (dated 1 July, 2008) suggests modernization of the education to train a competitive workforce with English language proficiency to substitute foreign specialists, while the State Program of Education Development in the Republic of Kazakhstan for 2011-2020 (dated 7 December, 2010) aims at the formation of an intellectually, physically and spiritually developed citizen of the Republic of Kazakhstan. It is planned that by 2020, almost $15 \%$ of the Kazakhstani adult population would speak fluently in three languages, Kazakh, Russian and English. In the current State Program of the development of education and science for 2020-2025 (dated December 27, 2019), improvement of the competitiveness of Kazakhstani education world-wide is pursued. In the model curricula of professionally-oriented foreign language, the following intended learning outcomes are noted: constantly enhance vocabulary, develop public speaking skills, be able to make a decision in any situation, identify the problem and find solutions, etc.

Although there is a positive trend in applying innovative teaching technologies and updated teaching textbooks and other learning materials, there are still some issues in Kazakhstani higher education system in reaching intended learning outcomes. Teaching professionally-oriented English language courses requires teachers' and students' awareness of the demands of contemporary workplace communicative competence; it demands much more than merely a sufficient level of English language proficiency from individuals. In Cameron (2002) it is stated that to communicate effectively in workplace settings, there is a need to speak fluently, truthfully and openly about one's feelings, and exercise assertiveness, once needed [6]. Recent graduates should have the ability to be tolerant in accepting points of view that differ from their own beliefs; they should be able to listen actively to different perspectives without pre-judging. Effective communication also requires the ability to interact with colleagues from different cultures, ethnicity, race, and religion.

Another issue concerns the expansion of vocational vocabulary that may not ensure successful communication in the workplace settings, unfortunately. Although various materials and communication techniques for communicative learning are available, teachers still seem to be using outdated teaching materials, while students seem to be overloaded with vocabulary memorization and translation tasks, as noted in Lengyelfalusyová \& Bakay Záhorská (2011) [7].

To examine the current state of affairs of professionally-oriented English language courses in the context of the Kazakhstani education system the following research question is pursued: what students' general perception of and attitude towards «professionally-oriented English language» course in higher education in Nur-Sultan, Kazakhstan?

\section{Experimental}

In this section, we report on the nature of the questionnaire, ethical considerations and stages of online survey and participants.

Questionnaire. The designed questionnaire (19 multiple choice questions and one open-ended question) consists of two sections. The first section contains the questions to gather some demographic data on participants (age, gender, year of study, etc.). The questions in the second section are designed to gather some data on the formation of the communicative competence of students. For example, to examine linguistic competence, the questions of English language proficiency before the course taken and after the course taken are asked. The question on further use of English language for potential professional development is also included in the questionnaire. Another group of questions (e.g. on ability to engage in communication and maintain interaction in English language) aims at examining the interactive competence of students. A question on the use of students' knowledge of foreign culture, customs and traditions in a professional setting examines students' sociolinguistic competence, while the questions on the use of innovative teaching methodology and students' opportunity to express their opinion in classroom settings reflect the use of current teaching methodologies. To see to what extent students may accept points of view that differ from their own beliefs, the questions on their ability to work in teams, to solve issues, understand and support their partners were included in the questionnaire. To receive general feedback on the course two questions are asked: «did you use the acquired knowledge of English language in the professional carrier so far?» and «was the course helpful for your professional career?». 
Procedure. The designed questionnaire was first sent to our colleagues for editing and commenting on the clarity, coherence of questions, and general feedback on the questions. Once returned with minor comments on the structure of the questionnaire, the form was revised. As university lecturers, we had an opportunity to approach students who have taken a «professionally - oriented English language course» in the past semester. The online questionnaire was sent to students' university emails (the total number was 79). Unfortunately, the request to participate in the study was ignored by students, and only a few filled-in questionnaire forms returned. Then, the online survey link, was sent around, directly to students through the WhatsApp messenger. Out of around 200 requests sent to participate in the study, over a one-week period in October 2020, we received 48 filled-in forms for the further analysis.

Ethical considerations. To pursue ethical considerations, students were informed that their participation in the survey is entirely voluntary, so they should not see their refusal to participate in the study as a potential issue that will negatively impact their academic performance. Students were also informed that all the identifiable information would be confidential and used for research purposes only.

Participants. The subjects of the study are students of bachelor's and master's courses from several universities in Nur-Sultan, Kazakhstan $(N=48$, mean age 26.5) recruited through the personal network as a snowball method.

\section{Results and discussion}

Upon the data analysis, positive discourse regarding the course has emerged. At the same time, there is not much improvement of linguistic skills is depicted.

Positive attitude towards the course. The respondents demonstrate that they have a clear understanding of the need to take the course as many of the indicate that the acquired skills would be helpful in their future careers. Below, there are some instances of students' opinion regarding the course:

(1) курс полезен для освоения иностранного языка

'The course is useful for mastering a foreign language'

(2) очень полезный

'very helpful'

(3) профессиональный английский язык полезен специалистам в любой сфере

'professional English is useful for professionals in any field'

(4) я думаю это очень нужный курс

'I think this is a necessary course'

(5) пригодился в работе

'useful at work'

(6) думаю, что данный курс помог мне улучшить мои навыки в понимании языка и помог мне приобретением профессиональных навыков в сфере моей специальности.

'I think this course helped me to improve my language comprehension skills and helped me to acquire professional skills in my field of specialization'.

(7) помогает понять и осмыслить, твоё ли это призвание

'it helps to understand and realize whether this is your true vocation'

(8) в данный момент я прохожу этот курс, и уверена, что курс «Профессионально-ориентированный иностранный язык» будет полезным для приобретения профессиональных навыков.

'at the moment I am taking this course, and I am sure that the course «Professionally oriented foreign language» will be useful for acquiring professional skills.'

(9) отличное дополнение к имеющимся знаниям.

'an excellent addition to my existing knowledge'

(10) для общения в иностранном коллективе курс оказался полезным, также для пополнения словаря новыми терминами в своей специализации.

'for communication in a foreign team, the course turned out to be useful, as well as for enhancing the vocabulary with new terms in my specialization'

(11) этот курс мне очень помог в поднятии уровня английского языка, а также закрепил мои базовые знания.

'the course helped me a lot in improving the level of English language proficiency. Also, it strengthened my basic knowledge'

(12) он был полезен тем, что я повысила разговорный скилл.

'it was helpful' because I improved my speaking skills' 
Although there were a very few students who noted that the course is not helpful enough or they felt indifferent towards taking the course.

(13) не полезен, так как не используется дальше

'not useful because it is not used further'

(14) относительно

'relatively'

(15) я до этого предмета знала английский, поэтому ничего особо сказать не могу

'I knew English before this subject, so I can't really say anything'.

Issues in teaching/learning professionally - oriented English language course. The data analysis revealed that students did not show a significant improvement in linguistic skills after completing the course (Table 1). There is an increase from $30.8 \%$ to $41 \%$ in the «intermediate» level of language, and from $17.9 \%$ to $23.1 \%$ in «upper-intermediate course», although the number of students with «beginner' and 'preintermediate' levels decreased (that is quite a positive trend).

T a b l e 1

\section{Students' English language proficiency before and after taking the course}

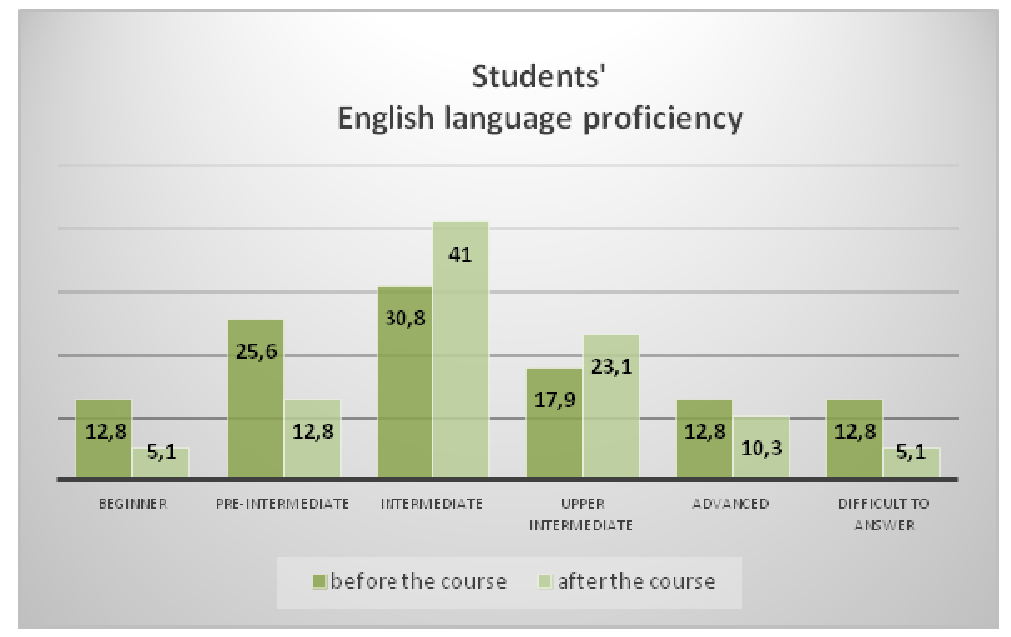

It seems that inadequate teaching materials (e.g. non-authentic materials) and traditional methods of teaching (e.g. teacher-centered, grammar-translation methods, memorization, etc.) negatively affected the students' learning outcomes. There could be some issues with students' motivation, involvement and participation in classroom activities, or low linguistic competence of the students.

As mentioned earlier, authentic materials, used in classroom, can stimulate learners to learn languages independently discovering and exploring the materials on their own. For the students with low language proficiency, authentic materials can be simplified with the use of relatively easy vocabulary, shorter texts and less demanding and assisted tasks (e.g. role-playing). To deal with students' low motivation, classroom activities should provide students with opportunities to make use of language they have so far, and perform classroom activities that reflect the course knowledge and practice. At the same time, students should be provided with instructional prompts from teachers as it is an important strategy of the active processing of the learning materials.

Another issue, revealed through the survey results analysis, is the fact that more than $33 \%$ of respondents rarely or almost never used the acquired English language skills for their further professional development. Although, it is true that almost $36 \%$ of respondents use English language for professional purposes (e.g. reading professional literature in English, see Table 2.)

Perhaps, such a pattern can be explained by the fact that many students still are full-time students at university, and still did not have a chance to get accepted for a full-time job. As a result, they have not experienced the need of English language proficiency for their professional development yet. Another explanation is that students have internships and work at local companies, and they do not work with documents in English language or encounter a foreign colleague. 


\section{Conclusion}

In this paper, the main issues in the formation of communicative competence in a professionally - oriented English language course at the university level are discussed. The survey among university students revealed that in general, they hold positive opinions towards the course. At the same time, however, they did not show sufficient improvement of the linguistic skills after the course completion.

Table 2

\section{Students' use of English language proficiency for professional development}

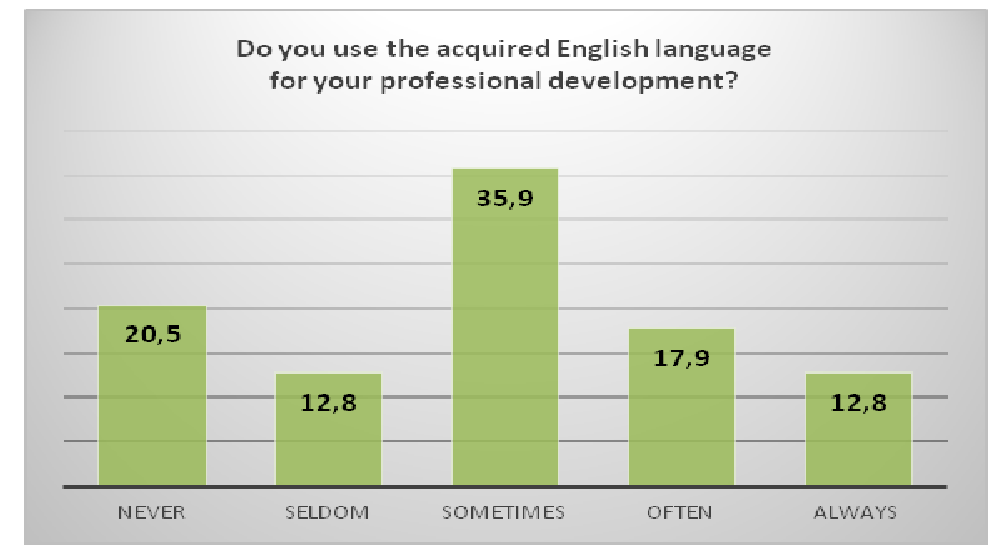

We argue that to reach the intended learning objectives of the course, there is a need for university teachers to create a more «authentic» environment in order to develop students' speaking skills, enhance creativity and imagination for the preparation of students for their future profession. To achieve this, the following measures (adapted from Lengyelfalusyová \& Bakay Záhorská, 2011) can be recommended:

- to create an authentic environment for language learners in order to practice situational conversations;

- provide students with authentic tasks to solve model situations;

- support communication in English language outside of the classroom;

- focus on teaching grammar in speaking activities [7].

Perhaps, the study results would have shown different patterns if more respondents had taken participation in the survey. Another issue concerns the online mode of collecting the filled-in forms. As a researcher, we could not control and see whether the respondents provided the well-thought and thoroughly considered answers. Perhaps, obtaining the qualitative data (e.g. interviews with students and teachers) on the course material, covered topics, tasks and classroom activities, pedagogical prompts would provide more insight into the issue.

\section{References}

1 Gondová, D., Sipošová, M. Teaching English: a guidebook for English Teacher Trainees. -Žilina: Edis, 2010.

2 Hymes, D. On communicative competence //Sociolinguistics. - 1972. -№ 3. - P. 269-293.

3 Canale M, Swain M. Theoretical bases of communicative approaches to second language teaching and testing //Applied linguistics. -1980. -T. 1. -№ 1. -P. 1-47.

4 Basturkmen H. Languages for specific purposes curriculum creation and implementation in Australasia and Europe // The Modern Language Journal. -2012. -№ 96. - P. 59-70.

5 Handoyo Puji Widodo. Teaching English for Specific Purposes (ESP): English for Vocational Purposes (EVP) in W.A. Renandya, H.P. Widodo (eds.), English Language Teaching Today, English Language Education. -2016. DOI 10.1007/978-3319-38834-2_19.

6 Cameron D. Globalization and the teaching of 'communication skills'// Globalization and language teaching. -2002. — - № 1. - P. 67-82.

7 Lengyelfalusyová, D. \& Bakay Záhorská, M. Investigating the English Language Needs of Students at the University of Zilina // Acta Technologica Dubnicae -2011. -T. 1 № 1. -P. 60-69. 


\author{
Г.Т. Уразбаева, А.А. Кабдиева
}

\title{
ЖОО-да сабақта коммуникативті құзыреттілікті қалыптастыру «Кәсіби бағытталған шет тілі»: проблемалар мен ұсыныстар
}

Кәсіби бағытталған ағылшын тілі курсының мақсаты студенттердің коммуникативті құзыреттілігін дамыту болып табылады, бұл өз кезегінде, студенттердің кәсіби саласында тілдік құзыреттілігін дамытуды көздейді. Мақалада коммуникативті құзыреттілікті қалыптастырудың негізгі мәселелері қарастырылған. Нұр-Сұлтан қаласындағы университеттің бакалавриат және магистратура бағдармаларының студенттері арасында жүргізілген сауалнамада $(N=48$, орташа жасы 26,5 жас) студенттер курсты аяқтағаннан кейін тілдік деңгейлерінде жеткілікті жетілдірулер байқамағанын көрсетті. Сауалнамада респонденттердің 33 \% -дан астамы алған білімдерін одан әрі кәсіби дамыту үшін сирек немесе мүлдем пайдаланбағанын жеткізді. Коммуникативті құзыреттілікті анағұрлым сәтті қалыптастыру үшін университет оқытушыларына арналған әдістемелік ұсыныстар (мысалы, студенттерді шығармашылық және қызықты тапсырмаларға тарту үшін «шынайы» материалдарды пайдалану) келтірілген.

Кілm сөздер: кәсіби бағытталған ағылшын тілі, коммуникативті құзыреттілік, лингвистикалық құзыреттілік, арнайы бағытталған тіл, кәсіби бағытталған тіл, студенттер, магистранттар, тілдік дағдылар.

\author{
Г.Т. Уразбаева, А.А. Кабдиева
}

\section{Формирование коммуникативной компетенции в вузе на занятиях «Профессионально-ориентированный иностранный язык»: проблемы и рекомендации}

\begin{abstract}
Целью профессионально-ориентированного курса английского языка является развитие коммуникативной компетенции студентов, которая, в свою очередь, предполагает развитие языковой компетенции студентов в их профессиональной сфере. В статье обсуждены основные вопросы формирования коммуникативной компетенции. Опрос, проведенный среди студентов и магистрантов вуза в НурСултане, Казахстан $(N=48$, средний возраст - 26,5 лет), показал, что студенты не продемонстрировали достаточного улучшения языковых навыков после завершения курса, и более 33 \% респондентов редко или почти никогда не использовали приобретенные знания английского языка для своего дальнейшего профессионального развития. Для более успешного формирования коммуникативной компетенции, авторами даны некоторые методические рекомендации (к примеру, использование более аутентичного материала для вовлечения студентов в творческие и увлекательные задания) для преподавателей вузов.
\end{abstract}

Ключевые слова: профессионально-ориентированный английский язык, коммуникативная компетенция, лингвистическая компетенция, язык для специальных целей, язык для профессиональных целей, студенты, магистранты, языковые навыки. 